\title{
Effect of water salinity on tissue mineralisation in Penaeus vannamei (Boone, 1931)
}

\author{
R. JANNATHULLA, J. SYAMA DAYAL, K. AMBASANKAR, V. CHITRA AND \\ M. MURALIDHAR \\ ICAR-Central Institute of Brackishwater Aquaculture, 75, Santhome High Road, RA Puram, Chennai - 600028 \\ Tamil Nadu, India \\ e-mail:syamdayal@rediffmail.com
}

\begin{abstract}
A 45-days indoor laboratory trial was performed with juveniles of Penaeus vannamei $(3.11 \pm 0.64 \mathrm{~g})$ to evaluate the effect of salinity on mineral contents in different tissues. Juveniles of $P$. vannamei were acclimatised to different salinity levels of $3,10,20,30,40,50$ and $60 \%$, using sea salt or freshwater at the rate of $2 \%$ per day from the original salinity. A total of 45 pre-acclimatised shrimps were taken for each treatment with three replications. At the end of the experimental period, shrimps were dissected to remove hepatopancreas, muscle and exoskeleton after collecting haemolymph; which were subjected to mineral analysis by Inductively Coupled Plasma-Optical Emission Spectrometry (ICP-OES). Calcium deposition was reduced by 55 and $40 \%$ in muscle and exoskeleton, respectively, whereas it increased by $142 \%$ in hepatopancreas of shrimp reared in $60 \%$ compared to $20 \%$ salinity. Magnesium and sodium content increased with increasing salinity in all the tissues except in muscle. Of all the macro elements, phosphorus (7.66 to $9.17 \mathrm{~g} \mathrm{~kg}^{-1}$ ) was high in muscle and calcium was predominant in exoskeleton (44.30 to $\left.79.98 \mathrm{~g} \mathrm{~kg}^{-1}\right)$, while sodium dominated in haemolymph (159.34-327.73 mmol 1-1) compared to other elements. Shrimps reared in various salinities did not show significant difference in nutritional value in terms of mineral content in muscle. Results indicated that $P$. vannamei is a very efficient osmoregulator in low saline environment, in particular at 10 to $30 \%$ compared to the extreme high saline environment (60\%).
\end{abstract}

Keywords: Daily value, Ionic profiles, Minerals, Penaeus vannamei, Salinity, Tissue mineralisation

Shrimp aquaculture production in India has crossed 4 lakh $\mathrm{t}$ during 2015-2016 compared to 1.44 lakh $\mathrm{t}$ during 2006-2007 (MPEDA, 2017). This jump in production was attributed to the introduction of specific pathogen free Penaeus vannamei to India during 2009. Several positive attributes associated with this species made it a preferred choice for shrimp farming and one among them is its wide tolerance to salinity. When shrimp is exposed to water with varying salinities, it undergoes homeostatic modifications and try to regulate its internal osmotic concentration in relation to the environment where it inhabits. In particular, $P$. vannamei effectively maintains the osmotic pressure and ionic regulation by exhibiting a pattern of hyper-osmosis and hypo-osmosis at low and high saline environment, respectively and strengthen its survival (Castille and Lawrence, 1981). This is one of the reasons which made $P$. vannamei a primary candidate species for shrimp farming in recent years. Despite the successful farming of $P$. vannamei, there are several issues to be resolved, such as variation in the physiological processes, including moulting frequency, oxygen consumption, osmolality, osmoregulation patterns, metabolism, nutrient utilisation and nitrogenous excretion (Rosas et al., 2001; ChongRobles et al., 2014). Although these issues are attributed to high stocking errors, improper farm management practises and environmental factors; vast majority of the previous reports evidenced that it is mainly due to the variation in the ionic profiles of the pond water (Saoud et al., 2003; Zhu et al., 2006; Roy et al., 2007).

In order to reduce these problems, both researchers and farmers employ various strategies, including the approaches of water modification by adding deficient minerals in low saline rearing medium and by pumping freshwater in high saline rearing medium in order to ensure successful production of shrimp (Roy and Davis, 2010). The minerals are also supplemented through the water (Pragnell and Fotedar, 2006) and diet (Zhu et al., 2006; Roy et al., 2007) to fulfil the nutritional requirement of cultured species. Partridge et al. (2008) reported that administration of minerals in water, in particular potassium, has been advantageous in shrimp and fish cultured at low salinity. In some places, where farmers rely on low saline artesian well water, unspecified quantity of fertilisers are used to correct ionic deficiencies without any scientific base (Roy and Davis, 2010). This approach increases the cost of shrimp production whereas; dietary supplementation of minerals provides considerable cost 
savings. However, a huge variation is noticed between the salinity and ionic profiles of water used for shrimp production, irrespective of the source. This phenomenon in turn affects the deposition of minerals in shrimp body and would cause alteration in metabolic functions and organ malfunction, finally leading to mortality (Saoud et al., 2003; Roy et al., 2007).

In our recent study (Jannathulla et al., 2017), the influence of water salinity (3 to 60\%) was investigated on growth and whole shrimp mineral composition in $P$. vannamei. The results revealed that in shrimps reared at extreme low (3\%o) and high (60\%) salinities, growth and mineral deposition were severely impacted. In addition, ionic profiles, in particular calcium, magnesium, potassium and sodium though, increased $(\mathrm{p}<0.05)$ in water with increasing salinity, the same trend did not reflect on shrimp body. The carcass mineralisation varied according to the minerals analysed which could be due to specific ionic regulation for each mineral in the shrimp (Jannathulla et al., 2017). The present study however, aimed to investigate the effect of a wide range of water salinity (3 to $60 \%$ ) on the mineral composition in different tissues viz., muscle, exoskeleton, hepatopancreas and haemolymph of $P$. vannamei. This database of mineralisation process in different tissues would help in dietary manipulations and/or in deciding the levels of mineral supplementation required according to the pond water salinity/ionic profiles.

The basal diet (Table 1) was prepared according to the nutritional requirement of $P$. vannamei using locally available ingredients as described by Dayal et al. (2013a). Briefly, all the dry ingredients were ground to $<250 \mu \mathrm{m}$ in a pulveriser, to which oil sources and additives were added. The mash was blended in an electric blender for $20 \mathrm{~min}$. The homogenised material was steamed at atmospheric pressure after making a dough using water $\left(500 \mathrm{ml} \mathrm{kg}^{-1}\right)$ and was pelletised in a table top pelletiser having $2 \mathrm{~mm}$ dia die. The pellets were dried at $60^{\circ} \mathrm{C}$ overnight in a hot air oven and stored in a plastic container at $4{ }^{\circ} \mathrm{C}$ until further use. Proximate composition of ingredients and basal diet (Table 1) was analysed as per AOAC (1997).

Juveniles of $P$. vannamei reared at $20 \%$ salinity were procured from a local farm near to Chennai, India and were acclimatised to indoor laboratory conditions for 15 days. The study comprised seven salinity treatments of $3,10,20$, $30,40,50$ and $60 \%$. The juveniles were randomly divided and acclimatised to experimental salinities by either stepwise increase in salinity using sea salt or stepwise decrease using freshwater at the rate of $2 \%$ per day from the original salinity of $20 \%$. During acclimatisation, shrimps were fed a diet having $38 \%$ crude protein and $6 \%$ lipid. Post-acclimatisation, a total of 45 healthy shrimps
Table 1. Ingredients and chemical composition of the experimental diet $\left(\mathrm{g} \mathrm{kg}^{-1}\right.$ as fed basis)

\begin{tabular}{|c|c|}
\hline \multicolumn{2}{|l|}{ Ingredient composition } \\
\hline Fishmeal $^{1}$ & 200 \\
\hline Acetes & 100 \\
\hline Soybean meal & 250 \\
\hline Sunflower oil cake & 50 \\
\hline Groundnut oil cake & 50 \\
\hline Wheat flour & 140 \\
\hline Maida & 100 \\
\hline Broken rice & 50 \\
\hline Fish oil $^{1}$ & 20 \\
\hline Lecithin & 10 \\
\hline Pre-mix ${ }^{2}$ & 20 \\
\hline Binder $^{3}$ & 10 \\
\hline \multicolumn{2}{|l|}{ Proximate composition } \\
\hline Moisture & 98.3 \\
\hline Crude protein & 381.5 \\
\hline Ether extract & 62.4 \\
\hline Crude fiber & 32.6 \\
\hline Nitrogen free extract ${ }^{4}$ & 295.1 \\
\hline Total ash & 130.1 \\
\hline \multicolumn{2}{|l|}{ Macro elements } \\
\hline Calcium & 30.07 \\
\hline Magnesium & 3.48 \\
\hline Phosphorus & 15.67 \\
\hline Potassium & 8.56 \\
\hline Sodium & 6.94 \\
\hline Ca:P ratio & 1.92 \\
\hline
\end{tabular}

${ }^{1}$ Bismi Fisheries, Mayiladuthurai, Tamil Nadu, India

${ }^{2}$ Pre-mix $\left(\mathrm{g} \mathrm{kg}^{-1}\right)$ : Thiamine hydrochloride $(25.50 \mathrm{~g})$, Riboflavin (25g), Prydoxinehydrochloride $(50 \mathrm{~g})$, Cyanogobalamine $(0.10 \mathrm{~g})$, Menadione $(5.00 \mathrm{~g})$, All-trans tocopherol acetate $(99 \mathrm{~g})$, Retinyl acetate (10 g), Vitamin D (50 g), Nicotinic acid (101 g), D-Ca-pantothenate $(61 \mathrm{~g})$, biotin $(25 \mathrm{~g})$, folic acid $(6.25 \mathrm{~g})$, inositol (153.06 g), ferric citrate $(13.70 \mathrm{~g}), \mathrm{ZnSO}_{4} \cdot 7 \mathrm{H}_{2} \mathrm{O}(28.28$ $\mathrm{g}), \mathrm{MgSO}_{4} \cdot 7 \mathrm{H}_{2} \mathrm{O}(0.12 \mathrm{~g}), \mathrm{MnSO} 4 . \mathrm{H} 2 \mathrm{O}(12.43 \mathrm{~g}), \mathrm{CuSO}_{4} .5 \mathrm{H}_{2} \mathrm{O}$ (19.84 g), $\mathrm{CoC}_{12} \cdot 6 \mathrm{H}_{2} \mathrm{O}(4.07 \mathrm{~g}), \mathrm{KIO}_{4}(0.03 \mathrm{~g}), \mathrm{KCl}$ (15.33 g), $\mathrm{Na}_{2} \mathrm{SeO}_{3}(0.02 \mathrm{~g})$

${ }^{3}$ Pegabind, Bentoli AgriNutrition Asia Pvt Ltd, Singapore

${ }^{4}$ Calculated by difference

$(3.11 \pm 0.64 \mathrm{~g})$ were used per treatment from the respective pre-acclimatised tanks with 3 replications each (15 shrimps per replication). Shrimps were randomly stocked in 5001 ( $1.31 \times 0.64 \times 0.73 \mathrm{~m})$ oval shaped fiberglass reinforced plastic (FRP) tanks. During the experimental period (45 days), shrimps were fed thrice a day at 0700 hrs, $1230 \mathrm{hrs}$ and $1730 \mathrm{hrs}$ at the rate of $6 \%$ biomass and the uneaten feed particles were siphoned off after $1 \mathrm{~h}$ of feeding time. Water quality parameters other than salinity viz., temperature $\left(26.5\right.$ to $\left.28.5^{\circ} \mathrm{C}\right)$, dissolved oxygen $(5.8$ to $\left.7.8 \mathrm{mg} \mathrm{l}^{-1}\right), \mathrm{pH}$ (8 to 8.5$)$ and total ammonia-nitrogen, $\mathrm{NH}_{3}-\mathrm{N}\left(<0.1 \mathrm{mg} \mathrm{l}^{-1}\right)$ in the rearing water were monitored and were found to be within the normal range. 
At the end of the experimental period, a total of 25 to 30 live shrimps at the inter-moult stage were collected from each treatment, except shrimps reared at 60\% (12 shrimps) and washed with deionised water. Haemolymph was collected through the ventral sinus in the first abdominal segment of shrimp using a 26-gauge hypodermic needle on $1 \mathrm{ml}$ syringe with $2 \mathrm{~mm}$ thickness without having any anticoagulant solution. Post-haemolymph collection, shrimps were dissected to remove hepatopancreas, muscle and exoskeleton. All the dissected tissues were rinsed again with deionised water and immediately stored at $-80^{\circ} \mathrm{C}$ until analysis. In order to have a representative sample, all the shrimps in the three replicate tanks in each treatment were pooled and represented as one replicate.

The daily value of muscle portion of shrimp reared at different saline water was calculated as per $\mathrm{FAO} / \mathrm{WHO} /$ UNU guidelines as cited by Dayal et al. (2013b) by taking $70 \mathrm{~kg}$ adult human recommended dietary allowances (RDA). One hundred grams of muscle was taken to calculate the daily value (\%) that was recommended as serving size of meat (Enser et al.,1996).

Daily value $(\%)=$ Level of mineral/RDA x 100

For mineral analysis, $1 \mathrm{~g}$ sample of the tissue was digested using microwave digestion method (Anton Par micro wave system) with $6 \mathrm{ml}$ of nitric acid and $2 \mathrm{ml}$ of hydrogen peroxide in inert polymeric microwave vessels. The vessels were sealed and heated in the microwave digestion system. The initial temperature was increased to $180^{\circ} \mathrm{C}$ and maintained at this level for $10 \mathrm{~min}$. An interval of $10 \mathrm{~min}$ was given for ramp and then decreased to $70^{\circ} \mathrm{C}$ for $8 \mathrm{~min}$. The vessels were kept in the same condition for $10 \mathrm{~min}$ for venting. The resulting solutions were cooled and diluted to a known volume $(25 \mathrm{ml})$ with deionised water. The minerals were determined using Inductively Coupled Plasma-Optical Emission Spectrometry (ICP-OES; Agilent 5100 SUV) using the software version 5.2. The analytical measurements were made with an auto sampler equipped with a peristaltic pump, across-flow nebuliser (coupled to a double pass spray chamber) and Quartz central torch tube injector with an internal diameter of $2 \mathrm{~mm}$. The analytical conditions were maintained at $0.81 \mathrm{~min}^{-1}$ nebuliser argon flow, $0.21 \mathrm{~min}^{-1}$ auxiliary flow and $151 \mathrm{~min}^{-1}$ plasma flow. The cyclonic spray chamber was used with RF power of $1300 \mathrm{~W}$. The diameter of the sample injector was $2 \mathrm{~mm}$ and the sample uptake was at the rate of $1.8 \mathrm{ml} \mathrm{min}^{-1}$. The autointegration period was between $5 \mathrm{~s}$ (minimum) and $20 \mathrm{~s}$ (maximum). Read and rinse delay was 60 and $20 \mathrm{~s}$ respectively during the analysis. The certified reference material of ICP multi-element standard solution (Merck) was used for calibration. The ranges of the calibration curves ( 5 points) were selected to match the expected concentrations of all the elements of the samples being analysed. The correlation coefficient (r) obtained for all cases was 0.9999 . However, the experimental water was directly used to analyse the mineral composition after filtering through a $0.2 \mu \mathrm{m}$ syringe filter (Jannathulla et al., 2017).

Mineral $\left(\mathrm{g} \mathrm{kg}^{-1}\right)=$ Instrument value $(\mathrm{g}) \mathrm{x}$ Dilution / Sample weight $(\mathrm{g})$

Statistical software, SPSS (Ver. 16) was used to analyse the experimental data. The normal distribution and homogeneity of variance were ascertained using normality and homogeneity test, respectively. One way analysis of variance (ANOVA) was employed to assess the effect of salinity on the mineral composition of different tissues of $P$. vannamei. Duncan's multiple range test was used to compare the mean values among the treatments when the differences were significant at $\mathrm{p}<0.05$.

The effect of water salinity on tissue mineralisation is presented in Table 2, 3, 4 and 5 for muscle, exoskeleton, hepatopancreas and haemolymph respectively. Water salinity significantly $(\mathrm{p}<0.05)$ affected the mineral content of $P$. vannamei which varied according to the tissues analysed. Of all the macro elements, phosphorus was found to be high in muscle ( 7.66 to $9.17 \mathrm{~g} \mathrm{~kg}^{-1}$ ) followed by potassium (6.64 to $7.86 \mathrm{~g} \mathrm{~kg}^{-1}$ ). Calcium was predominant in exoskeleton and was in the range of 44.30 to $79.98 \mathrm{~g} \mathrm{~kg}^{-1}$. The level of magnesium was low in hepatopancreas (1.13 to $1.53 \mathrm{~g} \mathrm{~kg}^{-1}$ ), while sodium dominated in haemolymph (159.34-327.73 mmol 1-1) compared to other elements. Our values corroborated with the findings of Cheng et al. (2006) in an exoskeleton portion of $P$. vannamei fed different dietary calcium and phosphorus; whereas they reported lower values in muscle and hepatopancreas compared to the present study. However, the values of haemolymph and hepatopancreas are comparable with the reports of Sowers et al. (2006) and Roy et al. (2007), respectively in $P$. vannamei. Differences in results are probably due to the variations in the ionic profiles of water used for culture.

Among the major elements, calcium plays important roles in crustaceans, including tissue hardening, blood clotting, muscle contraction, nerve transmission as well as osmoregulation and also act as a cofactor for various metabolic processes. Of all the tissues examined, the proportion of calcium was found predictably high in exoskeleton as it serves as an important element for calcification in hardening the cuticles. The level of calcium was not much affected in the tissues of $P$. vannamei reared in low saline water up to $30 \%$ whereas its level gradually decreased in muscle and exoskeleton and was gradually increased in hepatopancreas with increasing 
Table 2. Mineral composition ( $\mathrm{g} \mathrm{kg}^{-1}$ dry matter basis) of muscle tissue of Penaeus vannamei reared at different salinity levels ( $\mathrm{n}=3$ )

\begin{tabular}{|c|c|c|c|c|c|c|}
\hline \multirow{2}{*}{ Salinity treatments $(\%)$} & \multicolumn{4}{|c|}{ Mineral composition } & & \multirow{2}{*}{$\begin{array}{l}\mathrm{Ca}: \mathrm{P} \\
\text { ratio }\end{array}$} \\
\hline & Calcium & Magnesium & Phosphorus & Potassium & Sodium & \\
\hline 3 & $3.91^{\mathrm{d}}$ & $1.36^{\mathrm{ab}}$ & $9.17^{\mathrm{a}}$ & $7.89^{\mathrm{a}}$ & $3.63^{c}$ & $0.43^{\mathrm{c}}$ \\
\hline 10 & $5.31^{\mathrm{ab}}$ & $1.38^{\mathrm{ab}}$ & $8.85^{\mathrm{ab}}$ & $7.83^{\mathrm{ab}}$ & $4.11^{c}$ & $0.60^{\mathrm{b}}$ \\
\hline 20 & $5.06^{\mathrm{bc}}$ & $1.38^{\mathrm{ab}}$ & $8.65^{b}$ & $7.64^{\mathrm{ab}}$ & $3.70^{\mathrm{c}}$ & $0.59^{\mathrm{b}}$ \\
\hline 30 & $5.21^{\mathrm{abc}}$ & $1.49^{\mathrm{a}}$ & $8.21^{\mathrm{c}}$ & $7.12^{\mathrm{cd}}$ & $3.63^{\mathrm{c}}$ & $0.63^{\mathrm{b}}$ \\
\hline 40 & $5.65^{\mathrm{a}}$ & $1.40^{\mathrm{ab}}$ & $7.86^{\mathrm{cd}}$ & $6.64^{\mathrm{e}}$ & $4.08^{c}$ & $0.72^{\mathrm{a}}$ \\
\hline 50 & $4.79^{c}$ & $1.23^{\mathrm{bc}}$ & $7.66^{d}$ & $6.72^{\text {de }}$ & $4.91^{b}$ & $0.62^{b}$ \\
\hline 60 & $2.29^{\mathrm{e}}$ & $1.15^{\mathrm{c}}$ & $7.90^{\mathrm{cd}}$ & $7.38^{\mathrm{bc}}$ & $7.43^{\mathrm{a}}$ & $0.29^{\mathrm{d}}$ \\
\hline SEM & 0.037 & 0.007 & 0.023 & 0.042 & 0.048 & 0.001 \\
\hline $\mathrm{p}$ value & 0.000 & 0.034 & 0.000 & 0.000 & 0.000 & 0.000 \\
\hline CV $(\%)$ & 5.529 & 7.969 & 2.401 & 3.677 & 6.417 & 7.203 \\
\hline
\end{tabular}

Means bearing the same superscripts within the column do not differ significantly $(\mathrm{p}>0.05)$

Table 3. Mineral composition ( $\mathrm{g} \mathrm{kg}^{-1}$ dry matter basis) of exoskeleton of Penaeus vannamei reared at different salinity levels ( $\mathrm{n}=3$ )

\begin{tabular}{|c|c|c|c|c|c|c|}
\hline \multirow{2}{*}{ Salinity treatments $(\%)$} & \multicolumn{4}{|c|}{ Mineral composition } & \multirow[b]{2}{*}{ Sodium } & \multirow{2}{*}{$\begin{array}{l}\mathrm{Ca}: \mathrm{P} \\
\text { ratio }\end{array}$} \\
\hline & Calcium & Magnesium & Phosphorus & Potassium & & \\
\hline 3 & $79.98^{\mathrm{a}}$ & $2.76^{\mathrm{b}}$ & $13.14^{\mathrm{b}}$ & $4.49^{\mathrm{bc}}$ & $3.30^{\mathrm{bc}}$ & $6.09^{\mathrm{a}}$ \\
\hline 10 & $77.11^{\mathrm{ab}}$ & $3.23^{\mathrm{ab}}$ & $15.66^{\mathrm{ab}}$ & $4.58^{\mathrm{b}}$ & $3.29^{\mathrm{bc}}$ & $5.39^{\mathrm{a}}$ \\
\hline $20 \%$ & $73.57^{\mathrm{bc}}$ & $3.29^{\mathrm{a}}$ & $13.22^{\mathrm{b}}$ & $4.27^{\mathrm{bc}}$ & $3.02^{\mathrm{cd}}$ & $5.55^{\mathrm{a}}$ \\
\hline 30 & $78.21^{\mathrm{ab}}$ & $3.61^{\mathrm{a}}$ & $12.85^{\mathrm{b}}$ & $4.10^{\mathrm{cd}}$ & $3.10^{\mathrm{cd}}$ & $6.08^{\mathrm{a}}$ \\
\hline 40 & $69.56^{\mathrm{c}}$ & $3.59^{\mathrm{a}}$ & $17.82^{\mathrm{a}}$ & $5.22^{\mathrm{a}}$ & $2.79^{d}$ & $3.90^{\mathrm{b}}$ \\
\hline 50 & $56.03^{\mathrm{d}}$ & $3.64^{\mathrm{a}}$ & $18.64^{\mathrm{a}}$ & $4.04^{\mathrm{cd}}$ & $3.53^{\mathrm{b}}$ & $3.00^{\mathrm{b}}$ \\
\hline 60 & $44.30^{\mathrm{e}}$ & $3.56^{\mathrm{a}}$ & $17.61^{\mathrm{a}}$ & $3.65^{\mathrm{d}}$ & $5.42^{\mathrm{a}}$ & $2.51^{\mathrm{b}}$ \\
\hline SEM & 3.927 & 0.045 & 2.780 & 0.040 & 0.029 & 0.370 \\
\hline $\mathrm{p}$ value & 0.000 & 0.021 & 0.022 & 0.000 & 0.000 & 0.000 \\
\hline CV (\%) & 3.813 & 8.261 & 14.101 & 6.081 & 6.402 & 17.226 \\
\hline
\end{tabular}

Means bearing the same superscripts within the column do not differ significantly $(\mathrm{p}>0.05)$

Table 4. Mineral composition ( $\mathrm{g} \mathrm{kg}^{-1}$ dry matter basis) of hepatopancreas of Penaeus vannamei reared at different salinity levels ( $\mathrm{n}=3$ )

\begin{tabular}{|c|c|c|c|c|c|c|}
\hline \multirow{2}{*}{ Salinity treatments $(\%)$} & \multicolumn{5}{|c|}{ Mineral composition } & \multirow{2}{*}{$\begin{array}{l}\mathrm{Ca}: \mathrm{P} \\
\text { ratio }\end{array}$} \\
\hline & Calcium & Magnesium & Phosphorus & Potassium & Sodium & \\
\hline 3 & $5.59^{\mathrm{d}}$ & $1.16^{\mathrm{a}}$ & $6.71^{\mathrm{a}}$ & $7.88^{\mathrm{a}}$ & $6.67^{b}$ & $0.83^{\mathrm{d}}$ \\
\hline 10 & $5.37^{\mathrm{d}}$ & $1.39^{\mathrm{a}}$ & $7.20^{\mathrm{a}}$ & $8.26^{\mathrm{a}}$ & $7.03^{b}$ & $1.30^{\mathrm{c}}$ \\
\hline 20 & $6.16^{\mathrm{d}}$ & $1.20^{\mathrm{a}}$ & $4.73^{b c}$ & $6.51^{b}$ & $5.32^{\mathrm{c}}$ & $1.34^{\mathrm{c}}$ \\
\hline 30 & $6.66^{\mathrm{d}}$ & $1.45^{\mathrm{a}}$ & $5.09^{\mathrm{bc}}$ & $7.72^{\mathrm{a}}$ & $6.87^{\mathrm{b}}$ & $1.29^{\mathrm{c}}$ \\
\hline 40 & $9.68^{c}$ & $1.43^{\mathrm{a}}$ & $4.21^{\mathrm{c}}$ & $6.31^{\mathrm{b}}$ & $5.28^{\mathrm{c}}$ & $2.33^{b}$ \\
\hline 50 & $12.03^{b}$ & $1.53^{\mathrm{a}}$ & $4.92^{b}$ & $5.64^{\mathrm{c}}$ & $6.33^{\mathrm{b}}$ & $2.44^{\mathrm{b}}$ \\
\hline 60 & $14.91^{\mathrm{a}}$ & $1.13^{\mathrm{a}}$ & $4.83^{b c}$ & $6.70^{\mathrm{b}}$ & $12.80^{\mathrm{a}}$ & $3.07^{\mathrm{a}}$ \\
\hline SEM & 0.548 & 0.040 & 0.077 & 0.054 & 0.109 & 0.031 \\
\hline $\mathrm{p}$ value & 0.000 & 0.410 & 0.000 & 0.000 & 0.000 & 0.000 \\
\hline $\mathrm{CV}(\%)$ & 10.592 & 19.800 & 6.770 & 4.363 & 6.036 & 12.796 \\
\hline
\end{tabular}

Means bearing the same superscripts within the column do not differ significantly $(\mathrm{p}>0.05)$

water salinity, while it was high in haemolymph of shrimp reared at 20 and $30 \%$ (18.12 and $20.48 \mathrm{mmol} \mathrm{l}^{-1}$ ). This indicate that the storage of calcium was not identical among the tissues of shrimp living in different saline medium and was in agreement with the findings of $\mathrm{Li}$ and Cheng (2012) in P. vannamei reared at 4 to $34 \%$. Stevenson (1985) documented that crustaceans cultured in freshwater store calcium in various tissues, in particular exoskeleton for cuticular mineralisation. This could be a reason for such increase observed in calcium content in 
Table 5. Mineral composition ( $\mathrm{mmol}^{-1}$ ) of haemolymph of Penaeus vannamei reared at different salinity levels $(\mathrm{n}=3)$

\begin{tabular}{lllll}
\hline \multirow{2}{*}{ Salinity treatment $(\%)$} & \multicolumn{3}{c}{ Mineral composition } & Sodium \\
\hline 3 & Calcium & Magnesium & Potassium & $159.34^{\mathrm{d}}$ \\
10 & $16.56^{\mathrm{bc}}$ & $2.46^{\mathrm{c}}$ & $9.51^{\mathrm{ab}}$ & $170.39^{\mathrm{cd}}$ \\
20 & $17.32^{\mathrm{b}}$ & $3.07^{\mathrm{bc}}$ & $10.33^{\mathrm{a}}$ & $170.42^{\mathrm{cd}}$ \\
30 & $18.12^{\mathrm{b}}$ & $3.32^{\mathrm{bc}}$ & $9.08^{\mathrm{ab}}$ & $180.99^{\mathrm{c}}$ \\
40 & $20.48^{\mathrm{a}}$ & $3.65^{\mathrm{ab}}$ & $9.75^{\mathrm{a}}$ & $182.61^{\mathrm{c}}$ \\
50 & $17.37^{\mathrm{b}}$ & $3.77^{\mathrm{ab}}$ & $7.28^{\mathrm{cd}}$ & $200.52^{\mathrm{b}}$ \\
60 & $15.24^{\mathrm{cd}}$ & $3.88^{\mathrm{ab}}$ & $6.02^{\mathrm{d}}$ & $327.73^{\mathrm{a}}$ \\
SEM $( \pm)$ & $14.49^{\mathrm{d}}$ & $4.32^{\mathrm{a}}$ & $8.01^{\mathrm{bc}}$ & 36.348 \\
p value & 0.591 & 0.139 & 0.507 & 0.000 \\
CV $(\%)$ & 0.000 & 0.012 & 0.001 & 3.990
\end{tabular}

Means bearing the same superscripts within the column do not differ significantly $(\mathrm{p}>0.05)$

shrimp reared in a low saline environment in the present study. On the contrary, penaeid shrimps cultured in near full strength seawater need not require to store calcium in the tissues, since it is promptly available in high saline rearing medium. However, a reverse trend was observed in hepatopancreas where the calcium deposition was high at 50 and $60 \%$ than those reared between 3 and $40 \%$ (Table 4). Li and Cheng (2012) suggested that it could be due to the poor sensitivity of calcium transport mechanism in the hepatopancreas at extreme high salinities which lead to accumulation of calcium in the hepatopancreas. In our study, calcification in muscle and exoskeleton of $P$. vannamei was reduced by 55 and $40 \%$, respectively whereas it increased by $142 \%$ in hepatopancreas compared to shrimp reared at $20 \%$ (Fig. 1). Greenaway (1985) reported that the hepatopancreas and haemolymph is also a storage site for calcium in P. vannamei and would thus play important roles in calcium homeostasis. It is generally accepted that the hepatopancreatic cells play important role in massive calcium movements (Wheatly, 1999). However; the higher deposition of hepatopancreatic calcium reared at extreme high saline environment indicates that $P$. vannamei has poor calcium transport mechanism in such conditions.

Phosphorus is an important element having an integral role in all the energy yielding metabolic processes which also plays a major role in exoskeleton formation along with calcium. Any disturbance in phosphorus homeostasis, would have profound effects on metabolic reactions and organ functions (Lovell, 1991). Among the tissues analysed, phosphorus dominated in exoskeleton and was in the range of 13.14 to $18.64 \mathrm{~g} \mathrm{~kg}^{-1}$ followed by muscle ( 7.66 to $9.17 \mathrm{~g} \mathrm{~kg}^{-1}$ ) and hepatopancreas (4.21 to $7.20 \mathrm{~g} \mathrm{~kg}^{-1}$ ) whereas it was not detected in haemolymph. The results clearly indicate that phosphorus has a significant role in exoskeleton mineralisation. The deposition of phosphorus was found high in low saline rearing medium in both

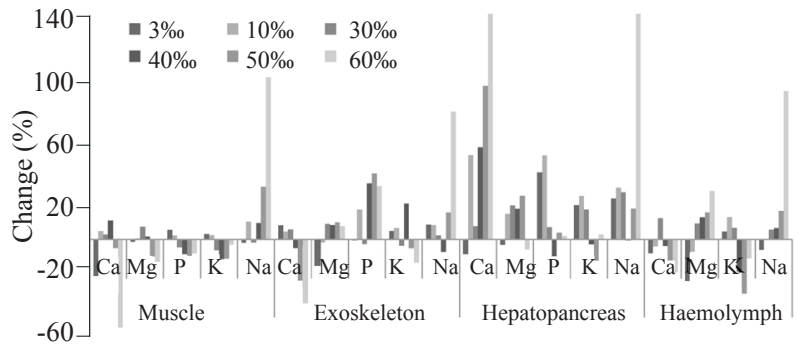

Fig. 1. Percentage change in mineral composition of different tisuue parts of Penaeus vannamei reared at different salinity levels compared to those reared at $20 \%$

muscle and hepatopancreas, whereas the reverse trend was noticed in exoskeleton. The trend of $\mathrm{Ca}: \mathrm{P}$ ratio was similar as in calcium and it gradually decreased from 0.43 to 0.29 in muscle and 6.09 to 2.51 in exoskeleton with increasing water salinity while it increased from 0.83 to 3.07 in hepatopancreas.

Magnesium is an essential element for crustaceans for normal functions, including osmoregulation, protein synthesis and for adequate growth. Magnesium content of muscle showed no significant difference in shrimp reared between 3 and $40 \%$ (1.36 to $1.49 \mathrm{~g} \mathrm{~kg}^{-1}$ ) and was noticeably $(\mathrm{p}<0.05)$ reduced to 1.23 and $1.15 \mathrm{~g} \mathrm{~kg}^{-1}$ in shrimp reared at 50 and $60 \%$, respectively. Both exoskeleton and haemolymph had significantly $(p<0.05)$ low levels of magnesium at $3 \%$ compared to other tissues, while no difference was noticed in hepatopancreas between the treatments. Jannathulla et al. (2017) reported poor survival of shrimp reared at $60 \%$ o $(\sim 27 \%)$ than those reared at 3 to $50 \%$ o $(75.53$ to $95.53 \%)$. The observed result could be attributed to the poor ionisation of magnesium at extreme hyper saline condition. Notwithstanding, Roy et al. (2007) stated that low level of magnesium increases respiratory rate and lead to stress, which could translate in to reduced survival and poor growth rate. 
Generally, the tissue potassium concentration is used as a practical indicator to determine the optimal dietary potassium level (Shiau and Hsieh, 2001) and is a major intracellular cation having an important role in electrolyte and acid-base balance of intracellular fluids. Though potassium level increased with increasing salinity in the present experimental water, its level was not much affected in the tissues analysed. Though difference was noticed between the treatments, it was insignificant compared to the difference observed in the case of other minerals. The trend was almost comparable with the findings of Jannathulla et al. (2017) who reported 6.85 to $8.35 \mathrm{~g} \mathrm{~kg}^{-1}$ of potassium in carcass of $P$. vannamei reared at 3 to $60 \%$. Zhu et al. (2006) suggested that this phenomenon would be due to the proper ion regulation and tissue mineralisation of potassium by P. vannamei. The deposition of potassium was increased in low saline rearing, in particular 3 and $10 \%$ in comparison with $20 \%$ irrespective of the tissues analysed (Fig. 1) indicating that $P$. vannamei has a very strong regulatory mechanism for this ion in secretion and reabsorption to maintain almost stable levels in all the tissues (Cheng et al., 2006). This finding is in agreement with that for other shrimp species such as $P$. monodon (Lin et al., 2000) and freshwater prawn, M. rosenbergii (Wilder et al., 1998). Sodium is an important osmolyte in crustaceans, including shrimp and its level was almost similar in muscle and exoskeleton while slightly higher values were observed in hepatopancreas. The level of sodium was more pronounced at $60 \%$ compared to other salinities, irrespective of the tissues analysed. Its level increased by $100.85 \%$ in muscle, $79.31 \%$ in exoskeleton, $140.74 \%$ in hepatopancreas and $92.31 \%$ in haemolymph of shrimp reared at $60 \%$ compared to shrimp reared at $20 \%$ whereas variation was much lower in other treatments (Fig. 1). This indicates that no proper ionic regulation and tissue mineralisation took place in $P$. vannamei when reared in extreme high saline condition.

The recommended daily allowance (RDA) was computed based on $\mathrm{FAO} / \mathrm{WHO} / \mathrm{UNU}$ guidelines to provide adequate nutrient required for a healthy person, but it would vary according to the age (children, adolescents and adults) and sex (male and female). In the present study, $100 \mathrm{~g}$ of muscle portion was taken into account to calculate the daily value of food (\%) for an adult man weighing $70 \mathrm{~kg}$ (Fig. 2). The FAO/WHO/UNU reports as cited by Dayal et al. (2013b) stated that the daily value of nutrients with $>70 \%$ is rated as outstanding, 50 to $70 \%$ as excellent, 20 to $50 \%$ as very good, 10 to $25 \%$ as good and $<10 \%$ as poor. Of all the analysed minerals, the daily value was found high in phosphorus and was in the range of 31.1 to $35.2 \%$. There was not much of difference in phosphorus daily value between the shrimps reared at 3 to $60 \%$ and hence were grouped under the category of very good source. The daily value of calcium was 19.2 to $23.0 \%$ in shrimp reared at 10 to $50 \%$ whereas the value was reduced in 3\%o (15.0\%) and 60\% (9.4\%); however; all were listed under the category of good. Magnesium (8.8 to $10.7 \%$ ), potassium (4.3 to $4.8 \%$ ) and sodium (4.0 to $5.7 \%$ ) had poor daily value, and water salinity did not lead to much of a difference between the treatments except for sodium at $60 \%$ o $(8.7 \%)$. The results corroborated with the findings of Dayal et al. (2013b).

From the present investigation, it can be concluded that changes in the water salinity have severe impact on tissue mineralisation in shrimp. However; efficient ionic regulation and tissue mineralisation was observed in $P$. vannamei at low saline environments, in particular 10 to $30 \%$ compared to the extreme high saline environment of $60 \%$. Moreover, there were not much of difference in the daily values of shrimp muscle according to water salinity.

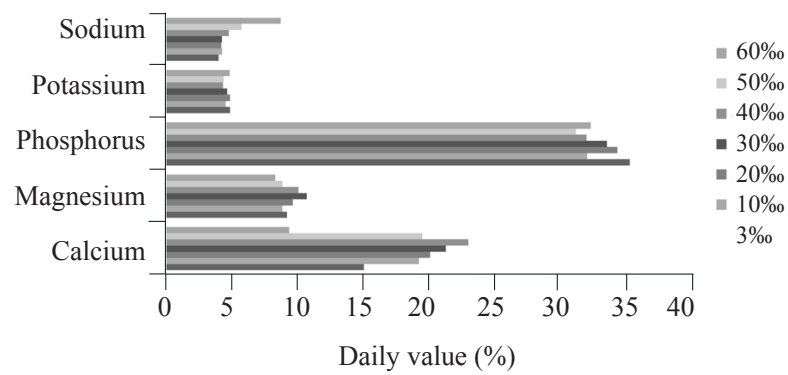

Fig. 2. Calculated daily value of macrominerals of edible part of Penaeus vannamei reared at different salinity levels

\section{Acknowledgements}

Authors express their sincere thanks to the present and former Directors, ICAR- CIBA, Chennai for extending all the infrastructure facilities. Financial support from Indian Council of Agricultural Research (ICAR), New Delhi through the project of National Innovation in Climate Resilient Agriculture (NICRA) is duly acknowledged.

\section{References}

AOAC 1997. Official methods of analysis. Association of Offical Analytical Chemists, $18^{\text {th }}$ edn. Benjamin Franklin Station, Washington DC, USA.

Castille, F. L. and Lawrence, A. L. 1981.The effect of salinity on the osmotic, sodium and chloride concentrations in the haemolymph of euryhaline shrimp of the genus Penaeus. Comp. Biochem. Physiol., Part A: Physiol., 68: 75-80. doi. org/10.1016/0300-9629(81)90320-0. 
Cheng, K., Hu, C., Liub, Y., Zheng, S. and Qi, X. 2006. Effects of dietary calcium, phosphorus and calcium/phosphorus ratio on the growth and tissue mineralisation of Litopenaeus vannamei reared in low-salinity water. Aquaculture, 251: 472-483. DOI: 10.1016/j.aquaculture.2005.06.022.

Chong-Robles, J., Charmantier, G., Boulo, V., LizarragaValdez, J., Enriquez-Paredes, L. M. and Giffard-Mena, I. 2014. Osmoregulation pattern and salinity tolerance of the white shrimp Litopenaeus vannamei (Boone, 1931) during post-embryonic development. Aquaculture, 422: 261-267. doi.org/10.1016/j.aquaculture.2013.11.034

Dayal, J. S., Ambasankar, K., Rajendran, R., Rajaram, V. and Muralidhar, M. 2013a. Effect of abiotic salinity stress on haemolymph metabolic profiles in cultured tiger shrimp Penaeus monodon. Int. J. Bio-Resour. Stress Manag., 4: 339-343.

Dayal, J. S., Ponniah, A. G., Khan, H. I., Babu, E. M., Ambasankar, K. and Vasagam, K. P. 2013b. Shrimps - a nutritional perspective. Curr. Sci., 104: 1487-1491.

Enser, M., Hallet, K., Hewitt, B., Fursey, G. A. J. and Wood, J. D. 1996. Fatty acid content and composition of English beef, lamb and pork at retail. Food Chem., 42: 443-456. DOI:10.1016/0309-1740(95)00037-2.

Greenway, P. 1985. Calcium balance and moulting in the Crustacea. Biol. Rev., 60: 425-454.

Jannathulla, R., Syama Dayal, J., Chitra, V., Ambasankar, K. and Muralidhar, M. 2017. Growth and carcass mineralisation of Pacific whiteleg shrimp Penaeus vannamei Boone 1931 in response to water salinity. Indian J. Fish., 64: 22-27. DOI: 10.21077/ijf.2017.64.2.59404-04.

Li, C. and Cheng, S. 2012. Variation of calcium levels in the tissues and haemolymph of Litopenaeus vannamei at various moulting stages and salinities. J. Crustacean Biol., 32: 101-108. DOI: 10.1163/193724011X615370.

Lin, S. C., Liou, C. H. and Cheng, J. H. 2000. The role of the antennal glands in ion and body volume regulation of cannulated Penaeus monodon reared in various salinity conditions. Comp. Biochem. Physiol. A., 127: 121-129. DOI:10.1016/s1095-6433(00)00245-2.

Lovell, R. T. 1991. Nutrition of aquaculture species. J. Anim. Sci., 69: 4193-4200.

MPEDA 2017. The Marine Products Exports Development Authority. http://mpeda.gov.in/MPEDA/\# (Accessed 18 March 2017).

Partridge, G. J., Lymbery, A. J. and George, R. J. 2008. Finfish mariculture in inland Australia: a review of potential water sources, species and production systems. J. World
Aquac. Soc., 39: 291-310. doi.org/10.1111/j.1749-7345. 2008.00169.x.

Pragnell, D. I. and Fotedar, R. 2006. The growth and survival of Western king prawn Penaeus latisulcatus Kishinouye in potassium-fortified inland saline water. Aquaculture, 259: 234-242. DOI: 10.1016/j.aquaculture.2006.05.023.

Rosas, C., Cuzon, G., Gaxiola, G., Le Priol, Y., Pascual, C., Rossignyol, J., Contreras, F., Sanchez, A. and Van Wormhoudt, A. 2001. Metabolism and growth of juveniles of Litopenaeus vannamei: effect of salinity and dietary carbohydrate levels. J. Exp. Mar. Biol. Ecol., 259: 1-22. DOI:10.1016/s0022-0981(01)00222-2.

Roy, L. A. and Davis, D. A. 2010. Requirements for the culture of the Pacific white shrimp, Litopenaeus vannamei, reared in low salinity waters: water modification and nutritional strategies for improving production. In: Cruz-Suarez, L. E., Ricque-Marie, D., Tapia-Salazar, M., Nieto-Lopez, M. G., Villarreal-Cavazos, D. A., GamboaDelgado, J. (Eds.), Progress in aquatic nutrition $X$ - Memoirs of the $X$ International Symposium on Aquatic Nutrition, 8-10 November 2010, Mexico, p. 61-78 (In Spanish).

Roy, L. A., Davis, D. A., Saoud, I. P. and Henry, R. P. 2007. Supplementation of potassium, magnesium and sodium chloride in practical diets for the Pacific white shrimp, Litopenaeus vannamei, reared in low salinity waters. Aquac. Nutr., 13: 104-113. doi.org/10.1111/j.1365-2095. 2007.00460.x.

Saoud, I. P., Davis, D. A. and Rouse, D. B. 2003. Suitability studies of inland well waters for Litopenaeus vannamei culture. Aquaculture, 217: 373-383. DOI:10.1016/S00448486(02)00418-0.

Shiau, S. Y. and Hsieh, J. F. 2001. Dietary potassium requirement of juvenile grass shrimp, Penaeus monodon. Fish. Sci., 67: 592-595. doi.org/10.1046/j.1444-2906.2001.00294.x.

Sowers, A. D., Young, S. P., Grosell, M., Browdy, C. L. and Tomasso, J. R. 2006. Haemolymph osmolality and cation concentrations in Litopenaeus vannamei during exposure to artificial sea salt or a mixed-ion solution: relationship to potassium flux. Comp. Biochem. Physiol. Part A: Mol. Integr. Physiol., 145: 176-180. DOI:10.1016/j. cbpa.2006.06.008.

Stevenson, J. R. 1985. Dynamics of the integument: Integument pigments and hormonal processes. In; Bliss, D. E. and Mantel, L. H. (Eds.), The biology of crustacean. Academic Press, New York, USA, p. 2-42.

Wheatly, M. G. 1999. Calcium homeostasis in Crustacea: the evolving role of branchial, renal, digestive and hypodermal epithelia. J. Exp. Zool. Part A: Ecol. Gen. Physiol., 283: 620-640. doi.org/10.1002/(SICI)1097-010X (19990601)283:7<620::AID-JEZ2>3.0.CO;2-3. 
Wilder, M. N., Ikuta, K., Atmomarsono, M., Hatta, T. and Komuro, K. 1998. Changes in osmotic and ionic concentrations in the haemolymph of Macrobrachium rosenbergii exposed to varying salinities and correlation to ionic and crystalline composition of the cuticle. Comp. Biochem. Physiol. A., 119: 941-950.
Zhu, C., Dong, S. and Wang, F. 2006. The interaction of salinity and $\mathrm{Na} / \mathrm{K}$ ratio in seawater on growth, nutrient retention and food conversion of juvenile Litopenaeus vannamei. J. Shellfish Res., 25: 107-112. doi.org/10.2983/07308000(2006)25[107:TIOSAK]2.0.CO;2. 